\title{
THE STUDY OF FEMINISM IN SELECTED WORKS OF SHOBHA DE
}

\author{
Sabina Ghai ${ }^{1}$, Krantipal Singh ${ }^{2}$, Vikramjit Singh ${ }^{3}$ \\ ${ }^{1}$ Assistant Professor, Chandigarh University, ghaisabina@gmail.com \\ ${ }^{2}$ Director, Nav Chintan Kala Manch, krantipalsingh80@gmail.com \\ ${ }^{3}$ Actor, Nav Chintan Kala Manch, lukeysingh@gmail.com
}

\begin{abstract}
Feminism relates to the belief that women should have the same the same social, economic and political rights. It questions the preconceived assumption about the roles that men and women should have in life, as they mostly work to the advantage of men over women. Feminism brings to scrutiny the portrayals of gender roles, which tend to impose social norms, customs, connections, laws and expectations on the grounds of gender discrimination. It can be considered as a movement which is fought against women oppression under patriarchy. It recognizes that having pleasure is central part of life and does not discourage woman who enjoys it without any sense of guilt or regret. Although it started as a mere 'consciousness', has now assumed a more emphatic voice. The new brave woman embraces beauty and power of sex to achieve present goals. They talk of freedom in sex as a human right; make all efforts to look glamorous and attractive, different from the traditional women. Many Indian writers in English have talked of this freedom and its manifestations. They present the issues regarding women in such a way that they lay bare the inner landscape of a woman's intimate experience that testifies her existence. It is through various other female characters that some significant issues pertaining gender bias, marriage, displacement, male-dominance and marginalization, will be resolved in the present article. The study seeks to explore and explicate the overall images of women and their lifestyle, from the Indian point of view. The emphasis is on the new emerging woman of modern cosmopolitan India, who is no more a puppet in the hands of a man.
\end{abstract}

Keywords: Feminism, Freedom in sex, Male-dominance, Patriarchy

\section{INTRODUCTION: FEMINISM}

The term 'Feminism' has its origin from the Latin word 'femina', meaning woman (through 'feminism'), and thereby refers to the advocacy of women's rights, status and power at par with men on the grounds of equality of sexes. In other words, it relates to the belief that women should have the same social, economic and political rights as men.

In the twentieth century, Simon de Beauvoir's 'Le Deuxiene Sexe' (1949), made an important landmark in the 
evolution of the feminist theory. In this, she examined the socio-economic, cultural, political and intellectual state of women. She questioned the status and role of women in the convention ridden patriarchal society. It says that a woman is not feminine by birth, but she is made so by the process of socio-cultural conditioning,

"One is not born, but rather becomes a woman. No biological, psychological or economic fate determines the Figure that the female presents in a society, it is civilization as a whole that produces this creature which is described as feminine."

But, for this it is extremely important to understand that 'sex' and 'gender' are two distinct terms. Sex' is a biological identity while 'gender' is a social construct. "Our sexuality and gender" as John Singleton observes, "shapes us like no other." Sex is identifiable by the reproductive functions of an individual whereas gender "is social expression of the basic psychological differences between men and women - social behavior which is deemed to be appropriate to 'masculine' or 'feminine' roles which is learned through primary and secondary socialization." Gender is therefore, determined by nature. It is the active process of 'gendering' that people undergo in a particular social milieu, which cause among them "sex exclusiveness and sex-preferential differentiation."

Largely speaking, the evolution of feminism can be studied under three different waves of feminist movement. The first wave is feminism which has been the political movement for women's rights. The second wave of feminism reveals the historical context of patriarchy and attacks the male domination in aggressive, militant tone. The third wave of feminism challenges the gender discrimination and attempts to a find a rational for the identities of masculinity and feminity separating men and women. The fourth wave of feminism may possible be the term for the post-modern feminism and, maybe called 'post feminism'; which lays emphasis on individual woman's inner freedom and awakening, on resolving the issues and problems raised by feminism and on understanding the relationship of interdependence between man and women. It covers the concept of the 'brave new world', 'the girl power', 'androgyny', 'pluralism' and to a certain extent the doctrine of 'multiculturalism'. The 'brave new world' and 'the girl power' refers to the world of young women who are bold, assertive, self assured and competitive, and do not require the crutches of feminism to secure space for themselves. The post feminism also includes the 'bad girls', who can counter men by their feminine will, and their assertive-aggressive sexuality.

\section{FEMINISM IN WORKS OF SHOBHA DE}

Feminism has carved a niche for itself in the Indian Literary scene as well, with its peculiar flavours unique to the Indian soil. Indian-English Literature has produced a galaxy of women writers touching various facets of women's life. While kamla Das has touched the physical aspects of human relationships, Anita Desai's focus is in the psychological one. In Bharathi Mukherjee it is a question of identity. Thus, the movement which was started as mere 'consciousness' in the Indian writers, has now assumed a more emphatic voice in writers like Shobha De.

Shobha De is one such woman writer who has attracted much attention and recognition not only in India, but all over the world as well. She has been regarded as, "the high priestess of gossip and innuendo." She began her advent in the literary scene in 1989 with Socialite Evenings, Starry Nights (1991), Sisters, Strange Obsession (1992), Sultry Days, Snapshots (1994) and many more works which have created furor in the Indian literary scene.

Through her works, she attempts to turn the pattern of displacement and marginalization upside down. De raises a voice of protest against male-dominance and constantly tries to shatter the patriarchal hegemony. She strives to undo the distorted image of a woman who cries for freedom and equality which goes unheard in the patriarchal world, for this, she explores the world of urban women in India. These modern women are more powerful than men. They are shown sexually liberated and have free thinking and hence have become 'New women'. The 'New woman' is a being in her own right who is in the process of becoming. She seeks fulfillment through self - expression in a social environment where there is mutuality, understanding and tenderness.

The strength of a woman is indeed the first and the most important aspect of De's novels. Her women represent an entirely different value system. Her characters in the novel, Nisha in Sultry Days, Aasha in Starry Nights, Karuna in Socialite Evenings, suffer from humiliation as far as their social, economic and cultural life is concerned; but, in addition to all this, these women are also fully capable of struggling, compromising and realizing their existence in the end.

The second aspect, which gains significance in De's novel, is marriage. She has given a totally new definition of marriage .Marriage, in her works, is contract of convenience where there is no place for marital fidelity and is not even considered by her female protagonists. The rich beautiful women are involved with 
men physically, but are not ready to abandon their freedom by getting married.

"You've dumped the guy.You are feeling right on top of everything powerful, strong and mainly free.

That's the happy part of the story."

De finds institution of marriage flawed, unnatural but fascinating. About women's liberation vis-à-vis marriage, she feels;

Women are driving the change. Power equation between a man and a woman has changed. It is the age of modern marriage, so is man ready to give in? There is resistance. He still favours the resistance quo because that goes to his advantage. But it's about time. For centuries men have dominated the socioeconomic scene and controlled marriages. But if this change is victimizing men and questioning their machismo, is woman to shoulder the blame for an unsuccessful marriage? There is nothing such as blame game, the moment it enters a marriage it's over. Marriage is a contract between two people who might be strangers or lovers".

Allied to the issue of marriage is the issue of sex. Nearly all her women have pre- marital sex. Sex is no longer a taboo to her women. She treats sex as an important aspect of one's life and does not hesitate to talk about it freely. De's novels include titillating details on sex which indicates the arrival of a new Indian woman eager to defy against the moral orthodoxy of the patriarchal social system. The woman would get sex on her own terms now. De adds that

"The very fact that sex is no longer the most dreaded and despised three-letter word in India is enough cause to celebrate. "

Socialite evenings (1989), the first novel of Shobha De is about the journey of a prominent Bombay socialite Karuna, from a staunch middle - class girl to a self - sufficient woman. Her quest to find out her 'self' springs from her discontentment from her own life which does not come up to her expectations. Her life is divided into three phases; life before marriage, married life and life after separating from her husband. Everything she does is a reaction against the puritanical world around her. Contrary to her father's wishes, she takes up modeling as a career and even acquires a boyfriend named Bunty. She announces her break up and soon decides to marry another man who entered her life.

Shobha De in this novel presents marriage as a contract, which is accepted by women as economic security, rather than physical or emotional fulfillment. Her protagonists are more worried about the economic status than social values and ethics related to marriage. Karuna's marriage soon starts falling apart since she realizes that she has married the wrong man - a rare acknowledgement found in our society. She herself contemplates at her failed marriage, "I didn't want to deaden myself to life." She ends up having an extramarital affair with her husband's friend Krish, which carries on for three years. Her divorce occurs when she becomes pregnant and her husband blames her with cheap remarks.

After her divorce, karuna takes up odd jobs and progresses rapidly with her hard work by doing odd jobs from script writing to ad-films. She excels rapidly and even bags the award as the copyright of the year. In the end, she confirms the idea of her state of living; "single was good for me"

Shobha De's famous but most controversial novel, Starry Nights took the literary world by storm for its frank portrayal of sex and exploitation. The novel is a faithful portrayal of the Mumbai film world, with all its glamour, deceits and physical exploitation of women. The protagonist, Aasha Rani, on her road to stardom manipulates many men, right from the level of assistant producer, to important underworld dons and industrialists. Thus, beating men at their own game is the strategy that Aasha Rani resorts to throughout the novel.

Nearly all Shobha De's women have pre-marital sex because it is not a taboo for them. The moment their marriages fail, her women go out in search of new relationships. Similarly, in Starry Nights, the moment Aasha Rani realizes that her husband has drifted away from her, she enters into a physical relationship with Suhas, an art-film director. Shobha De states that

"with the Satanic seductions and boundless libidinal energy, Aasha Rani and the likes of her enslave the males and become successful."

Sultry Days (1994), Shoha De writes on the very first page of the novel, "finally a book by me that they (her children) can read." In this novel, once again, De has presented the mainstream new woman. The novel is about an impressionable teenage, Nisha, who meets God in college and is attracted to him because he is a mixture of opposites. After college, God gets into journalism while Nisha takes up a job in an advertising 
agency. God's career taking an upward turn marks the death of the visionary in him. Soon, he starts sinking in the estimate of Nisha. By not becoming a part of God's pseudo commitments, Nisha begins to discover her own commitments. Her commitment is towards a certain cause of exposing Yashwantbhai and his underworld connections. Thus, by dedicating herself to a 'cause', Nisha's character rises.

The neo- rich Indians in De' novel, particularly educated, beautiful, attractive, competent and confident socialite women seem to define marriage afresh. The Khanna's and Barooha's typify dissipated marriages as De typifies:

"They'd been married for five years now. Five stormy, tempestuous years. It was the second time round for both of them. His first wife Karen had left him for his best friend; while Ruki had driven her husband to suicide...... She was looking for home. But not just home. Preferably, a penthouse"

\section{CONCLUSION}

It is through these and many other series of female characters that Shobha De has tried to shed some significant light on the important issues pertaining gender bias and marriage. Thus, Shobha De has touched upon different aspects of urban woman's life and her plight, but no issue has received the same kind of expression as the question of feminism. Attention has been drawn by other writers to woman's exploitation, discrimination and co modification, but De's voice is the most striking one. De has presented the issues regarding women in such a way that they lay bare the inner landscape of a woman's intimate experience that typifies her existence.

Thus, overall it can be assertively concluded that women with a better control and placidity in their attitudes and desires are easily outplaying their male counterparts. The 'New Woman' of today is no longer a flower in the hands of a man. Women today indulge in unconventional sexual behaviors to challenge and reject male domination. This type of behavior forms their efforts to gain true liberation as a woman. No doubt, at some point they become submissive to the males, but in the end they rise like a phoenix and represent a new woman to the society. Thus, Shobha De's woman violates all the social norms and rises out of all these norms in a new form, as a 'New Woman'

\section{REFERENCES LIST}

Simone de Beauvoir, The Second Sex, ed by H.M. Parshley, (London: Jonathan Cape, 1983)

John Singleton's: The Writing Self" in The Creative Writing" Workbook, (New York; Palgrave, 2001)

Ruth Robbins, Literary Feminism [London: Macmillam press Ltd., 2000]

Shobha De, Speed post.

S.P.Swain, "Shobha De's Socialite Evening - A Feminist study, Feminist English Literature.

K.Meerabai, "Feminism as an Extension of Existentialism woman in Indian English Fiction". Indian women Novelists, ed. R.K. Dhawan

Interview with Shobha De : Day by De Guide to Marital Bliss

Khushwant Singh and Shobha De, Uncertain Liaisons (Vikings, Penguin India, 1993)

S.P. Swain's "Shobha De's Socialite Evenings: A Feminist Study" in Feminist English Literature, ed by Manmohan K. Bhatnagar (New Delhi: Atlantic, 1999) 